\title{
Diplom, brev og budskap
}

Det er stas å bli godkjent spesialist - det burde i hvert fall være det. Men det kommer ikke frem i godkjenningsbrevet fra Helsedirektoratet.

Omstendighetene ville det slik at mine to legenevøer nylig ble godkjent som spesialister på samme tid - den ene i fødselshjelp og kvinnesykdommer i Australia, den andre i anestesiologi i Norge. Mens min nevø i Australia fikk et flott diplom (fig 1), måtte min nevø i Norge nøye seg med et to siders godkjenningsbrev.

Brevet er svært byråkratisk i form og innhold, uten skriftlig signatur og ender slik: «I medhold av lov om helsepersonell

«Spesialistgodkjenning er resultatet av et langt og krevende utdanningsløp og bør markeres»

m.v. av 2. juli 1999 nr. $64 \S 53$, jf. $§ 51$, jf. forskrift om spesialistgodkjenning av helsepersonell av 21. desember 2000 nr. 1384 og tilhørende bestemmelser, innvilges Thomas Leif Dolven spesialistgodkjenning $\mathrm{i}$ anestesiologi.»

Stilen minner om en byggetillatelse for en garasje. Ingen anerkjennelse, gratulasjoner eller begeistring. Budskapet kan lett oppfattes på denne måten: Vi bryr oss ikke. Dette er ikke viktig. Men vi har gått med på at du kan godkjennes som spesialist.

Brevet koster ham 4500 kroner.

\section{Spesialist og mester}

Vi har liten tradisjon for høytid, ritualer og diplomer i Norge. Diplomet som jeg - og mine samtidige - fikk ved norsk spesialistgodkjenning for mange år siden, er enklere enn det min nevø i Australia fikk. Få norske leger setter et slikt diplom i glass og ramme og henger det på veggen på legekontoret, slik det er vanlig i blant annet USA og andre land. Selv har jeg diplomet for min medisinske doktorgrad fra Universitetet i Oslo i glass og ramme, og jeg har vært i mange frisørsalonger der innehaverens frisørmesterdiplom - i nydelig kunstnerisk utforming - henger på veggen. Diplomer fra barneskirenn har verken jeg eller mine nevøer tatt vare på. Holdningen til diplomer varierer altså fra person til person og med hva man ønsker å vise frem.

Nevøen min i Norge vil ha diplomet sitt. Jeg forstår ham godt. Spesialistgodkjenning er resultatet av et langt og krevende utdanningsløp og bør markeres med noe mer enn et tørt, kaldt, upersonlig og byråkratisk brev.

Helsedirektoratet bør vurdere å omgjøre sin beslutning om ikke lenger å utstede diplom ved spesialistgodkjenning av leger (1). Dette kan kanskje bidra litt til å fremme tilhørighet og lojalitet til helsevesenet og motvirke en gryende fremmedgjøring og industrialisering av systemet. Helsedirektoratet bør også føye til på slutten av godkjenningsbrevene en setning som denne: $\mathrm{Vi}$ gratulerer med godkjenningen som spesialist og ønsker deg lykke til videre i ditt arbeid.

\section{Petter Gjersvik}

petter.gjersvik@medisin.uio.no

Petter Gjersvik (f. 1952) er førsteamanuensis og undervisningsleder i hud- og veneriske sykdommer ved Det medisinske fakultet ved Universitetet i Oslo.

Forfatter har fylt ut ICMJE-skjemaet og oppgir ingen interessekonflikter.

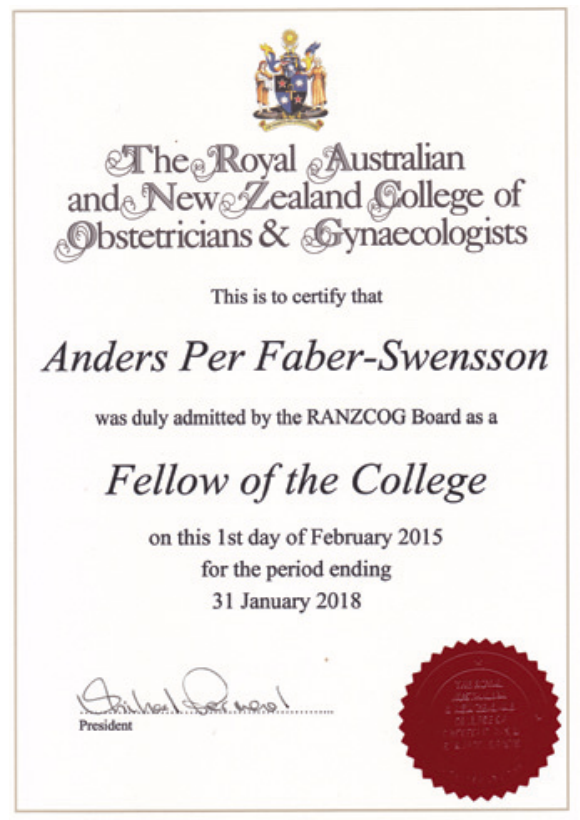

Figur 1 Spesialistdiplom i Australia fra 2015

\section{Litteratur}

1. Helsedirektoratet. Avvikler diplomordning for spesialistgodkjenning. 10.11.2014 https://helsedirektoratet.no/Om/nyheter/ Sider/avvikler-diplomordning-forspesialistgodkjenning.aspx (10.2.2015).

Mottatt 23.2. 2015 og godkjent 13.3. 2015. Forfatteren er redaktør i Tidsskriftet. Manuskriptet er derfor behandlet eksternt av en uavhengig redaktør, Pål Gulbrandsen.

Publisert først på nett. 